\title{
Asparagus racemosus (Willd) of Indian Origin: in Terms of Physico- Chemical, Phyto-Chemical and Nutritional Profiles
}

\author{
Karunarathne Y.A.U.D ${ }^{1^{*}}$, Amarasinghe A.P.G ${ }^{1}$, Weerasooriya T.R ${ }^{2}$, Samarasinghe U.K.A ${ }^{3}$, Arawwawala L.D.A.M ${ }^{3}$ \\ ${ }^{1}$ Department of Prasutitantra Kaumarabhrithya, Institute of Indigenous Medicine, University of Colombo, Sri Lanka \\ ${ }^{1}$ Senior Professor, Department of Prasutitantra Kaumarabhrithya, Institute of Indigenous Medicine, University of Colombo, Sri Lanka \\ ${ }^{2}$ Senior Professor Faculty of Medicine, Kotelawala Defense University, Ratmalana, Sri Lanka \\ ${ }^{3}$ Industrial Technology Institute, Bauddhaloka Mawatha, Colombo 7, Sri Lanka
}

\begin{abstract}
DOI: $10.36348 / \mathrm{sijtcm} .2020 . \mathrm{v} 03 \mathrm{i} 07.002$
| Received: 02.07.2020 | Accepted: 10.07.2020 | Published: 16.07.2020

*Corresponding author: Y.A.U.D. Karunarathne
\end{abstract}

\section{Abstract}

Asparagus racemosus Willd belongs to the plant family Asparagaceae and one of the well-known medicinal plants used in indigenous systems of medicine of Sri Lanka. It has abundant medicinal effects such as aphrodisiac, antioxidant, immunostimulant, antihepatotoxic, antibacterial, antidiabetic, anticarcinogenic, antidiarrheal, antiulcerogenic, antioxytocic, etc. Local suppliers for A. racemosus cannot meet the country requirement and therefore, mainly depends on imported $A$. racemosus grown in India. Therefore, an attempt was taken to evaluate the physico-chemical, phytochemical and nutritional profile of A. racemosus grown in India. Results revealed that $6.2 \pm 0.1 \%$ of total ash, 1.9 $\pm 0.0 \%$ of water-soluble ash and $1.7 \pm 0.0 \%$ of acid insoluble ash were contained in roots of $A$. racemosus grown in India. Total phenolic content, total flavonoid content and total saponin content were $14.0 \pm 0.1 \mathrm{mg}$ gallic acid equivalents/g of extract $7.1 \pm 0.2 \mathrm{mg}$ quercetin equivalents/g of extract and $4.5 \pm 0.2 \%$ respectively for A. racemosus grown in India. Twelve prominent spots bearing $\mathrm{R}_{\mathrm{f}}$ values of $0.07,0.09,0.12,0.20,0.25,0.28,0.36,0.48,0.54,0.71,0.89$ and 0.93 were present in Indian origin A. racemosus. Heavy metals such as $\mathrm{Hg}, \mathrm{As}, \mathrm{Cd}$ and $\mathrm{Pb}$ and microorganisms including Staphylococcus aureus, Escherichia coli, Coliforms, Salmonella and yeast and moulds were not detected in A. racemosus roots. Energy value of $A$. racemosus grown in India was $22 \mathrm{kcal} / 100 \mathrm{~g}$. In conclusion, present study illustrates a clear idea of physico-chemical, phytochemical and nutritional properties of $A$. racemosus grown in India.

Keywords: Asparagus racemosus, physico-chemical and phyto-chemical analysis, nutritional properties.

Copyright @ 2020: This is an open-access article distributed under the terms of the Creative Commons Attribution license which permits unrestricted use, distribution, and reproduction in any medium for non-commercial use (NonCommercial, or CC-BY-NC) provided the original author and source are credited.

\section{INTRODUCTION}

Herbal medicine remains important resources of healthcare worldwide that are reported to be safe and produce minimum side effects compared to synthetic medicines. However, there is still a significant lack of research on quality assessment and incorrect identification. Adulterations of plant ingredients for genuine plants cause lesser efficacy of the finished formulations.

A. racemosus Willd is a woody climber (1 to 2 $\mathrm{m}$ in height) belongs to the plant family Asparagaceae. The leaves are like pine needles, small and uniform and flowers are white and have small spikes [1]. It possesses a number of pharmacological activities such as aphrodisiac, antioxidant, immunostimulant, antihepatotoxic, antibacterial, antidiabetic, anticarcinogenic, antidiarrheal, antiulcerogenic, antioxytocic, etc [2, 3]. A. racemosus almost dies or dries up in summers and it grows with new tender branches from underground root. Flowers begin to appear in September-December and fruits appear afterwards [4].

The roots of A. racemosus is a heavily used in Sri Lanka for Ayurveda and traditional medicines. Local suppliers for A. racemosus cannot meet the country requirement and therefore, to fulfill the gap, roots of A. racemosus are imported. According to the importers of herbal medicines, A. racemosus is mainly imported from India. In a previous study, phytochemical, physico-chemical and nutritional profile was evaluated for A. racemosus grown in Sri Lanka [5]. When there is a scarcity of $A$. racemosus, imported $A$. racemosus is used to prepare Ayurveda or traditional medicines. Hence, an attempt was taken to evaluate the phytochemical, physico-chemical and nutritional profile of $A$. racemosus grown in India. 


\section{MATERIALS AND METHODS}

Collection and preparation of plant material

The roots of $A$. racemosus of Indian origin were supplied by Shree Dhootapapeswar Company, India with the authentication certificate. Roots were washed, cut into small pieces, dried at $40{ }^{\circ} \mathrm{C}$ for three days, crushed and powdered by using a commercial grinder and kept in an air tight container until used.

\section{Physico-chemical parameters}

Moisture, total ash, water soluble ash and acid insoluble ash contents were determined for $A$. racemosus root powder according to the WHO guidelines [6].

\section{Phytochemical screening}

Presence or absence of phytochemicals such as saponins, tannins, alkaloids, flavonoids, terpenoids, phenols and steroid glycosides were screened according to the standard protocols $[7,8]$ using dichloromethane extracts of $A$. racemosus roots.

\section{Quantification of total polyphenol content and total flavonoid content \\ Total polyphenol content [9] and flavonoid content [10] were determined according to the standard methods.}

\section{Quantification of saponins}

Saponins were determined using the method described by Obadoni and Ochuko [11]. In brief, $20 \mathrm{~g}$ of $A$. racemosus roots were added to a conical flask containing $100 \mathrm{ml}$ of $20 \%$ aqueous ethanol and heated over a hot water bath for $4 \mathrm{~h}$ with continuous stirring at about $55{ }^{\circ} \mathrm{C}$. The mixture was then filtered and the residue again extracted with another $200 \mathrm{~mL}$ of $20 \%$ ethanol. The combined extract was reduced to $40 \mathrm{ml}$ over a water bath, transferred to a $250 \mathrm{ml}$ separatory funnel and $20 \mathrm{~mL}$ diethyl ether added with vigorous shaking. The aqueous layer was recovered while the ether layer was discarded. The purification process was repeated. Then, $60 \mathrm{ml}$ of $\mathrm{n}$-butanol was added. The combined n-butanol extract was washed twice with 10 $\mathrm{mL}$ of $5 \%$ aqueous sodium chloride. The remaining solution was heated in a water bath. After evaporation, the sample was dried in the oven to a constant weight, and saponin content calculated as a percentage.

\section{Thin Layer Chromatography (TLC) fingerprint \\ TLC fingerprint was developed for} dichloromethane extract of $A$. racemosus roots.

\section{Dichloromethane extract}

Sample $(5 \mathrm{~g})$ was taken into a around bottom flask and dichloromethane $(100 \mathrm{~mL})$ was added. The contents were shaken well and a reflux condenser was attached to the flask and boiled gently for $2 \mathrm{~h}$, allowed to cool and filtered rapidly using a dry filter paper (Qualitative filter paper, 90mm Diameter Whatman (®). Then the filtrate was transferred to a round bottom flask and evaporated to dryness under the reduced pressure (at $40{ }^{\circ} \mathrm{C}$ ) using a rotor vapor and stored at $4{ }^{\circ} \mathrm{C}$ until use.

\section{Mobile phase}

About $8 \mu 1$ of the extract was spotted on TLC plate and fingerprint was developed in methanol: ethyl acetate: dichloromethane: cyclohexane at a ratio of $0.2: 1: 4: 6 \mathrm{v} / \mathrm{v} / \mathrm{v}$.

\section{Heavy metal content}

Quantitative determination of As [12], $\mathrm{Hg}$ [13], Cd [14] and $\mathrm{Pb}$ [12] was carried out according to Association of Official Agricultural Chemists (AOAC) methods using an Inductively Coupled Plasma Mass Spectrometry.

\section{Microbial limits}

Microbial tests for aerobic plate count [15], coliform count [16], yeasts and moulds count [17], Escherichia coli [18], Salmonella [19] and Staphylococcus aureus [20] were carried out as per standard procedures detailed in Sri Lanka Standards.

\section{Nutritional values}

Crude protein: Crude protein was determined by the Kjeldahl method describes in UDK 139 operating manual of VelpScient.

Total fat: Total fat was determined according to method described in operating manual of Gerhardt fat extractor.

Crude fibers: Crude fibers were determined using method described in operating manual of FOSS fibertec system which was adopted for AOAC 962.

Carbohydrate: Carbohydrate was determined by the calculation using crude protein, fat, crude fat, ash and moisture content.

Energy value: Energy value was calculated by using the calorie values of protein, fat and carbohydrates.

\section{STATISTICAL ANALYSIS}

Data were expressed as Mean \pm SEM.

\section{RESULTS AND DISCUSSION}

Many medical effects of $A$. racemosus have been reported in Indian and the British Pharmacopoeias and also in indigenous systems of medicine in Sri Lanka. The genus Asparagus consisted of about 300 species around the world, out of them 22 species are found in India [3]. Results revealed that $6.2 \pm 0.1 \%$ of total ash, $1.9 \pm 0.0 \%$ of water-soluble ash and $1.7 \pm 0.0 \%$ of acid insoluble ash were contained in roots of $A$. racemosus grown in India. Total ash content and watersoluble ash content were significantly higher in $A$. racemosus grown in Sri Lanka [5] compared to that of 
Indian grown A. racemosus. The total ash measures the total amount of material remaining after ignition and consists of carbonates, phosphates, silicates and silica, which include both physiologic ash and non physiologic ash. A high ash value is a good indicator of contamination, substitution, adulteration of a drug [21]. Water soluble ash is that part of the total ash content, which is soluble in water.

Phytochemicals such as saponins, tannins, alkaloids, flavonoids, terpenoids, phenols and steroid glycosides were present in A. racemosus roots. Therapeutically more important phytochemicals such as phenols, flavonoids and saponins were quantified using standard methods. Polyphenols in plant extracts react with Folin-Ciocalteu reagent to form a blue complex that can be quantified by visible light spectrophotometry. The reaction forms a blue chromophore constituted by a phosphotungsticphosphomolybdenum complex $[22$, 23], where the maximum absorption of the chromophores depends on the alkaline solution and the concentration of phenolic compounds. The flavonoid content was obtained using aluminum chloride colorimetric technique. This assay is based on the formation of a complex between the aluminum ion, $\mathrm{Al}$ (III), and the carbonyl and hydroxyl groups of flavones and flavonols that produce a yellow color [24]. Total phenolic content and total flavonoid content were 14.0 $\pm 0.1 \mathrm{mg}$ gallic acid equivalents $/ \mathrm{g}$ and $7.1 \pm 0.2 \mathrm{mg}$ quercetin equivalents/g of extract respectively for $A$. racemosus grown in India. Both total phenol content and flavonoid content were higher in Indian grown $A$. racemosus compared to that of Sri Lankan $A$. racemosus. Moreover, $4.5 \pm 0.2 \%$ saponin was present in A. racemosus of Indian origin. Twelve prominent spots bearing $\mathrm{R}_{\mathrm{f}}$ values of $0.07,0.09,0.12,0.20,0.25$, $0.28,0.36,0.48,0.54,0.71,0.89$ and 0.93 were present in Indian origin A. racemosus. Heavy metals such as $\mathrm{Hg}, \mathrm{As}, \mathrm{Cd}$ and $\mathrm{Pb}$ and microorganisms including Staphylococcus aureus, Escherichia coli, Coliforms, Salmonella and yeast and moulds were not detected in A. racemosus roots. Nutritional properties of $A$. racemosus grown in India are listed in Table 1. Crude protein and crude fiber were significantly higher in Sri Lankan grown A. racemosus than that of Indian grown plant. However, carbohydrate content was significantly lower in Sri Lankan origin A. racemosus than that of Indian origin. Energy value of $A$. racemosus grown in Sri Lanka (180 kcal/100g) was more than 8 folds higher than that of Indian grown A. racemosus (22 kcal/100g) $[5,25]$.
Table-1: Nutritional properties of Asparagus racemosus grown in India

\begin{tabular}{|l|l|}
\hline Nutritional properties & Percentage (\%) \\
\hline Crude protein & $5.6 \pm 0.0$ \\
\hline Total fat & less than $1 \%$ \\
\hline Crude fiber & $18.5 \pm 0.1$ \\
\hline Carbohydrate & $58.6 \%$ \\
\hline Energy value & $22 \mathrm{kcal} / 100 \mathrm{~g}$ \\
\hline
\end{tabular}

$\mathrm{N}=3$, Data expressed as Mean $\pm \mathrm{SEM}$

\section{CONCLUSION}

In conclusion, present study illustrates a clear idea of physico-chemical, phytochemical and nutritional properties of $A$. racemosus grown in India. Therefore, selection of $A$. racemosus grown in India as (a) an ingredient for polyherbal preparation or (b) a medicine itself will be easier for physicians.

\section{REFERENCES}

1. Alok, S., Jain, S. K., Verma, A., Kumar, M., Mahor, A., \& Sabharwal, M. (2013). Plant profile, phytochemistry and pharmacology of Asparagus racemosus (Shatavari): A review. Asian Pacific journal of tropical disease, 3(3), 242-251.

2. Bopana, N., \& Saxena, S. (2007). Asparagus racemosus-Ethnopharmacological evaluation and conservation needs. Journal of ethnopharmacology, 110(1), 1-15.

3. Singla, R., \& Jaitak, V. (2014). Shatavari (asparagus racemosus wild): a review on its cultivation, morphology, phytochemistry and pharmacological importance. International Journal of Pharmacy \& Life Sciences, 5(3).

4. Shirkande, A.S., Shirkande, A.A. (2019). Asparagus recemosus (Shatavari): A comprehensive Ayurvedic approach. Indian Journal of Applied Research, 9(8): 27-28.

5. Karunarathne, Y.A.U.D., Arawwawala, L.D.A.M., Amarasinghe A.P.G., Weerasooriya, T.R., Samarasinghe, U.K.A. (2019). Physico-chemical, Phytochemical and nutritional profiles of root powder of Asparagus recemosus (Willd) of Sri Lankan origin. Asian Journal of Pharmacognosy, 3(3); 29-35.

6. Quality Control for Medicinal Plant materials WHO, Geneva. ${ }^{\text {st }}$ : A.I.T.B.S. 2011; Publisher New Delhi 110051 (India)

7. Dahanayake, J.M., Perera, P.K., Galappatty, P.G., Perera, H.D.S.M., Arawwawala, L.D.A.M. (2019). Comparative Phytochemical analysis and antioxidant activities of Tamalakyadi decoction with its modified dosage forms. Evidence Based Complementary and Alternative Medicine. Article ID 6037137. 
8. Karunakaran, R., Thabrew, M.I., Thammitiyagodage, G.M., Galhena, B.P., Arawwawala, L.D.A.M. (2017). The gastroprotective effect of ethyl acetate fraction of hot water extract of Trichosanthes cucumerina Linn and its underlying mechanisms. BMC Complementary and Alternative Medicine, 17:312.

9. Singleton, V. L., Orthofer, R., \& LamuelaRaventós, R. M. (1999). [14] Analysis of total phenols and other oxidation substrates and antioxidants by means of folin-ciocalteu reagent. In Methods in enzymology (Vol. 299, pp. 152-178). Academic press.

10. Meda, A., Lamien, C. E., Romito, M., Millogo, J., \& Nacoulma, O. G. (2005). Determination of the total phenolic, flavonoid and proline contents in Burkina Fasan honey, as well as their radical scavenging activity. Food chemistry, 91(3), 571577.

11. Obadoni, B. O., \& Ochuko, P. O. (2002). Phytochemical studies and comparative efficacy of the crude extracts of some haemostatic plants in Edo and Delta States of Nigeria. Global Journal of pure and applied sciences, 8(2), 203-208.

12. AOAC International. (2012a). "Official Methods of Analysis of AOAC International", in AOAC International, Garthersburg, USA, 975.03.

13. AOAC International. (2012b). "Official Methods of Analysis of AOAC International", in AOAC International, USA, 999;10,

14. Cunniff, P. (1997). Official methods of analysis of aoac international. Journal of AOAC International, 80(6), 127A.

15. Sri Lanka Standards Institution. (2013a). Sri Lanka standards, Sri Lanka Standards Institution, Sri Lanka, 516/1, Section 1.
16. Sri Lanka Standards Institution. (1991). Sri Lanka standards, Sri Lanka Standards Institution, Sri Lanka, 516/2, Section 2.

17. Sri Lanka Standards Institution. (2013b). Sri Lanka standards, Publication of Sri Lanka Standards Institution, Sri Lanka, 516/3, Section 1.

18. Sri Lanka Standards Institution. (2013c). Sri Lanka standards, Publication of Sri Lanka Standards Institution, Sri Lanka, 516/12.

19. Sri Lanka Standards Institution. (2013d). Sri Lanka standards, Publication of Sri Lanka Standards Institution, Sri Lanka, 516/5.

20. Sri Lanka Standards Institution. (1992). Sri Lanka standards, Publication of Sri Lanka Standards Institution, Sri Lanka, 516/6.

21. Mukherjee, P.K. (2002). Quality Control of Herbal Drugs. New Delhi, India: Business Horizons.

22. Schofield, P., Mbugua, D.M., Pell, A.N. (2001). Analysis of condensed tannins: A review. Anim. Feed Sci. Tech, 91, 21-40.

23. Gülçin, I., Sat, I.G., Beydemir, S., Elmastas, M., Küfrevioğlu, Ö.I. (2004). Comparison of antioxidant activity of clove (Eugenia caryophylata Thunb) buds and lavender (Lavandula stoechas L.). Food Chem, 87, 393-400.

24. Popova, M., Bankova, V., Butovska, D., Petkov, V., Damyanova, B. N., Sabatini, A. G., Marcazzan, G. L., \& Bogdanov, S. (2004). Validated methods for the quantification of biologically active constituents of poplar-type propolis. Phytochemical Analysis, 15, 235-240. PMid:15311843

25. Kumari, S., Gupta, A. (2016). Utilization of Ashwagandha, Ginger and Shatavari root powder for the preparation of value added cheela. International Journal of Home Science, 2(3), 68-70. 